\title{
Evaluation of the Genetic Diversity of the Ryukyu Long-furred Rat (Diplothrix legata) on Northern Okinawa-jima Island, Japan
}

\author{
Tsukasa OKANO ${ }^{1)} *$, Manabu ONUMA ${ }^{1)}$ and Katsushi NAKATA ${ }^{2)}$ \\ 1) Center for Environmental Biology and Ecosystem Studies, National Institute for Environmental Studies, \\ Tsukuba, Ibaraki 305-8506, Japan \\ 2) Yambaru Wildlife Conservation Center, Ministry of the Environment, Kunigami, Okinawa 905-1413, Japan
}

[Received 26 September 2014; accepted 12 January 2015]

\begin{abstract}
We examined the partial mitochondrial DNA sequences of the Ryukyu long-furred rats (Diplothrix legata) on northern Okinawa-jima Island to evaluate the genetic diversity of this species. Complete mitochondrial D-loop (40-933) and partial tRNA-Pro (1-39) and Phe (934-961) sequences, totaling 961 bp in length, were determined for 60 individuals. Three D-loop haplotypes were present in these animals, with mutations at six sites (GenBank accession numbers: AB699876-AB699878). The haplotype diversity (H) and the nucleotide diversity ( $\pi$ ) of the D-loop sequences were 0.606 and 0.00238 , respectively. The "twin-peak" phenomenon was observed for the mismatch distribution of pairwise differences, indicating that the population of these animals had experienced a population bottleneck.
\end{abstract}

Key words: D-loop, genetic diversity, Ryukyu long-furred rat

— Jpn.J.Zoo. Wildl. Med. 20(1): 9-14, 2015

The Ryukyu long-furred rat (Diplothrix legata) is endemic to Japan and is distributed on Amami-ohshima Island, Tokunoshima Island, and Okinawa-jima Island of the Nansei Islands (Fig. 1A, B) [1]. This species is one of the largest rodents in Japan; its population is in decline because of its limited habitat range, decreasing habitat quality, and predation by introduced species including the small Indian mongoose (Herpestes auropunctatus) and feral cats and dogs [2, 3]. It is listed as Endangered (EN) in the IUCN Red List of Threatened Species [2] and the Red list of Threatened mammals of Japan [4], and its conservation is urgently required.

In the area of the present study, northern Okinawa-jima Island, evergreen broad-leaved forest dominated by Castanopsis sieboldii is spreading. Many endemic and rare species also inhabit this region, including the Okinawa rail (Gallirallus okinawae), Okinawa woodpecker (Sapheopipo noguchii), and Okinawa spiny rat (Tokudaia muenninki).

Understanding genetic diversity is important to the

\footnotetext{
* Corresponding author:

Tsukasa OKANO (E-mail: okano.tsukasa@nies.go.jp)
}

conservation of endangered species. Inbreeding depression, decreased immunity, and decreased adaptive evolution ability are caused by low genetic diversity, which can increase the possibility of extinction [5]. In this study, we examined the mitochondrial DNA D-loop region and partial t-RNA-Pro and Phe sequences of Ryukyu long-furred rats from northern Okinawa-jima Island, and we evaluated the genetic diversity of this species.

Sixty free-ranging Ryukyu long-furred rats that were thought to have been killed by vehicles or accidently captured in mongoose traps were collected by the Ministry of the Environment, Government of Japan in northern Okinawajima Island $\left(26^{\circ} 40^{\prime}-26^{\circ} 50^{\prime} \mathrm{N}, 128^{\circ} 05^{\prime}-128^{\circ} 20^{\prime} \mathrm{E}\right)$ from January 2007 to February 2012 (Fig. 1C and Appendix 1). The liver, muscle, and bone marrow samples were collected from these specimens and used for DNA extraction. These samples were cryopreserved in the Environmental Specimen Time Capsule Building, National Institute for Environmental Studies, Japan. DNA extraction was performed using an EZ1 DNA Tissue Kit (Qiagen) following the manufacturer's instructions. Mitochondrial DNA D-loop region and partial t-RNA-Pro and 


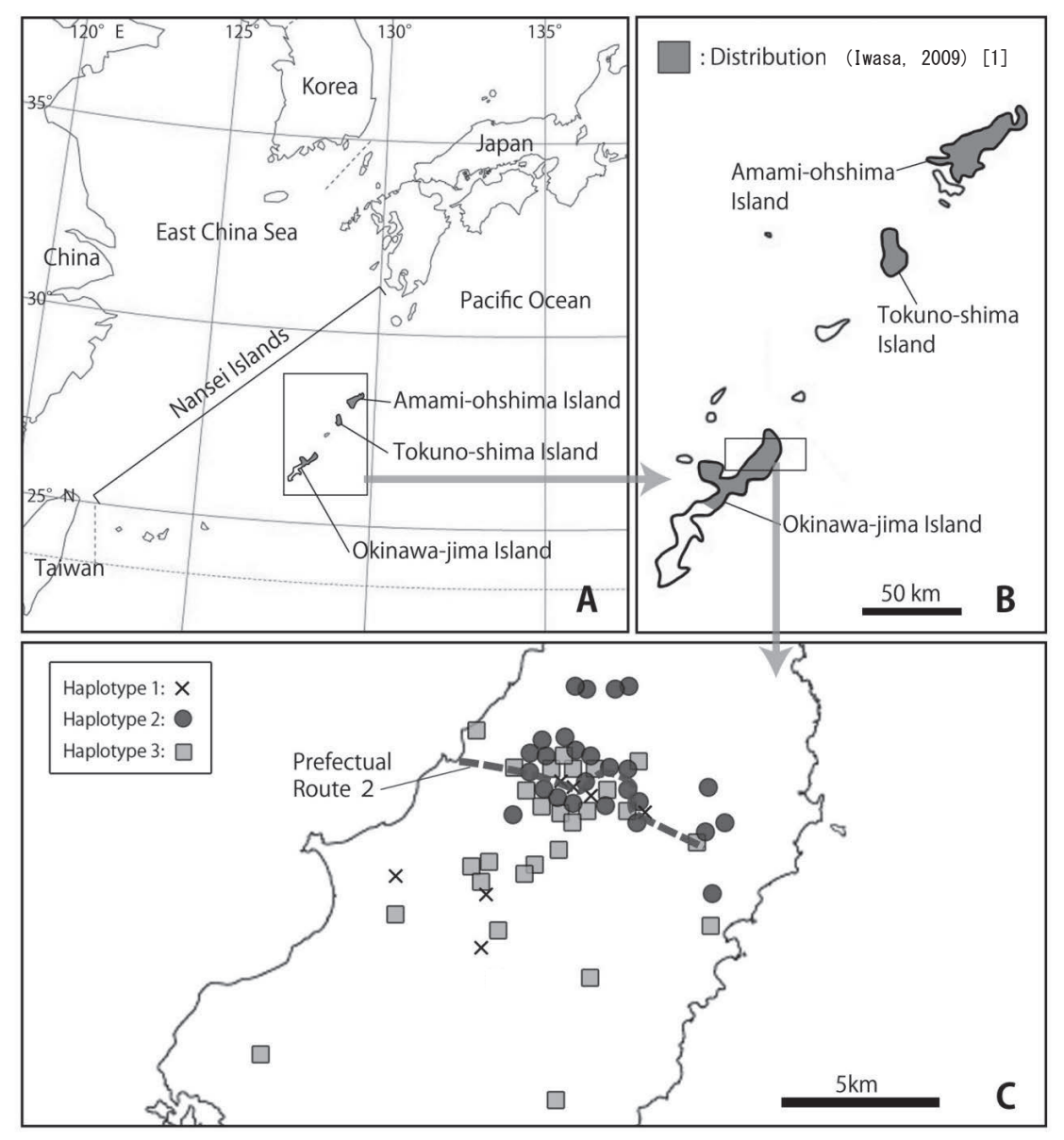

Fig. 1 Geographic distribution of the Ryukyu long-furred rat (Diplothrix legata) (A, B) and the sampling site for this study in northern Okinawa-jima Island (C). We determined the sequence of the mitochondrial DNA D-loop region. Three haplotypes were observed.

Phe sequences were amplified using the primer pair RLFRDloopF/RLFRD-loopR, which was designed for this study (Table 1). AmpliTaq Gold® PCR Master Mix (Applied Biosystems) was used to conduct a polymerase chain reaction (PCR) for gene amplification in a final reaction volume of $50 \mu \mathrm{l}$, following the manufacturer's instructions. Amplification was performed on a T3000 Thermocycler (Biometra) with the following protocol: an initial denaturation step at $95^{\circ} \mathrm{C}$ for $10 \mathrm{~min}$; 35 cycles of denaturation at $95^{\circ} \mathrm{C}$ for $30 \mathrm{~s}$, annealing at $55^{\circ} \mathrm{C}$ for $30 \mathrm{~s}$, and extension at $72^{\circ} \mathrm{C}$ for $1.5 \mathrm{~min}$; and a final extension at $72^{\circ} \mathrm{C}$ for 5 min. The PCR products were run on 2.0\% agarose gel and purified using the MiniElute PCR Purification Kit (Qiagen).

The purified PCR products were sequenced using the BigDye
Table 1 Ryukyu long-furred rat (Diplothrix legata) D-loop amplification primer sequences

\begin{tabular}{ll}
\hline \multicolumn{1}{c}{ Primer code } & \multicolumn{1}{c}{ Nucleotide sequence } \\
\hline RLFRD-loopF & 5' -TCA ACA CCC AAA GCT GAT ATT CT-3' \\
RLFRD-loopR & 5' -TGC TTT GCT TTA TTA TAA GCT ACA TT-3' \\
RLFRD-loopF2 & 5' -GAT GCC TTC AGT CAA CAT AGC-3' \\
RLFRD-loopR2 & 5' -ACC AAT TGA TGG CCC TGA AGT-3' \\
\hline
\end{tabular}

Terminator v3.1 Cycle Sequencing Kit (Applied Biosystems) and Applied Biosystems 3130 genetic analyzer (Applied Biosystems). The same primers were employed as those used for the PCR reactions, as well as the two internal primers 
RLFRD-loopF2/RLFRD-loopR2, which were designed for this study (Table 1). The sequences were aligned using the BioEdit sequence alignment editor ver. 7.0.9.0 (Tom Hall). After alignment, 961 base pairs (bp) of the complete D-loop and partial tRNA-Pro and Phe regions were obtained.

The statistical analyses for the D-loop were performed using DnaSP v5 [6]. A phylogenetic tree for the D-loop haplotypes, with the Norway rat (Rattus norvegicus) as an outgroup, was constructed utilizing the neighbor-joining (NJ) method [7] with MEGA6 [8]. Genetic distances were computed using the TajimaNei method [9]. The bootstrap consensus tree was inferred from 1,000 replicates [10].

Complete mitochondrial D-loop (40-933) and partial tRNAPro (1-39) and Phe (934-961) sequences, totaling $961 \mathrm{bp}$ in length, were determined for 60 individuals. Three D-loop haplotypes were present in the Ryukyu long-furred rats of northern Okinawa-jima Island, with mutations at six sites (GenBank accession numbers: AB699876-AB699878; Table 2). The haplotypes 1, 2, and 3 were present in 7 (11.7\%), 26 (43.3\%), and 27 (45.0\%) individuals, respectively. Haplotype 2 seems to be more closely related to haplotype 3 than haplotype 1 , but their relationship is unclear, due to low bootstrap value (78\%). Haplotype diversity $(\mathrm{H})$ and nucleotide diversity $(\pi)$ of the D-loop were 0.606 and 0.00238 , respectively; these values were higher than those of the endangered Okinawa rail of northern Okinawa-jima Island (0.499 and 0.00146, respectively) [11]. On the other hand, $\mathrm{H}$ and $\pi$ in the Ryukyu long-furred rat were lower than those of the large Japanese field mouse (Apodemus speciosus) (0.70-0.80 and 0.013-0.029, respectively) collected from six habitats linked by forests or green tract [12]. The large Japanese field mouse is a species of the same murine subfamily and is distributed in mainland Japan.

The "twin-peak" phenomenon was observed for the mismatch distribution of pairwise differences among haplotypes (Fig. 2), which is affected by past population events [13, 14]. The peak in the mismatch distribution was comparable to the population expansion period, and the trough between the peaks is comparable to a period of decline [15]. This result indicates that the population of Ryukyu long-furred rats has experienced a population bottleneck. The same phenomenon was observed in the Japanese rock ptarmigan (Lagopus mutus japonicas), an endangered alpine bird that experienced a bottleneck [15, 16]. Although twin peaks can be observed when contact has occurred with other populations that have different haplotypes, such contact is unlikely for the Ryukyu long-furred rat because of the isolation of the island. Moreover, relatively high $\mathrm{H}$ and low $\pi$ values in the examined population also support the occurrence of a genetic bottleneck [17].

Many extinct plant and animal species have inhabited islands [18]. Island populations generally have lower genetic variation than do mainland populations [19, 20]. Island populations are thought to suffer increased inbreeding relative to mainland populations because of bottlenecks in the founding group and

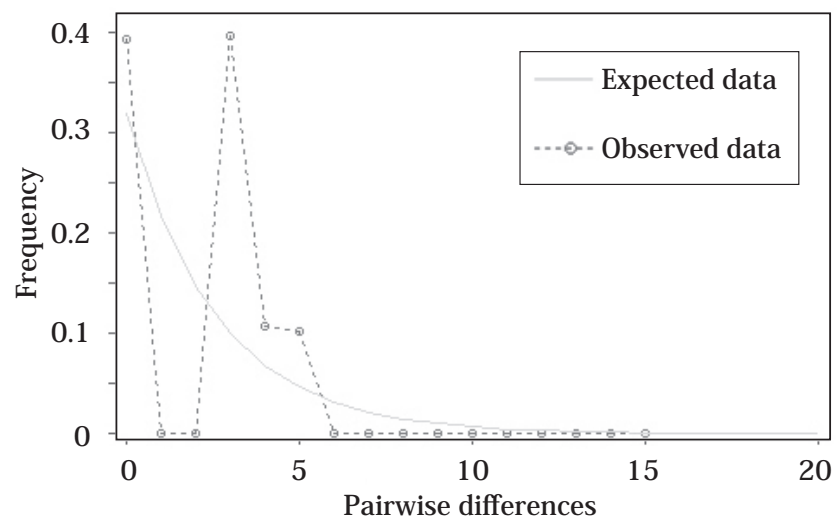

Fig. 2 Mismatch distribution of 60 mtDNA D-loop sequences of Ryukyu long-furred rats (Diplothrix legata) in northern Okinawa-jima Island.

Table 2 Position of the mutation in D-loop haplotypes of the Ryukyu long-furred rat (Diplothrix legata) distributed in northern Okinawa-jima Island.

\begin{tabular}{|c|c|c|c|c|c|c|c|c|}
\hline \multirow{2}{*}{ Haplotype } & \multirow[b]{2}{*}{$\mathrm{n}$} & \multicolumn{6}{|c|}{ Mutation site in D-loop region } & \multirow{2}{*}{ Accession No. } \\
\hline & & 61 & 134 & 143 & 177 & 219 & 578 & \\
\hline Haplotype 1 & 7 & $\mathrm{C}$ & $\mathrm{C}$ & $\mathrm{T}$ & A & C & G & AB699876 \\
\hline Haplotype 2 & 26 & $\mathrm{C}$ & $\mathrm{T}$ & $\mathrm{C}$ & G & $\mathrm{T}$ & $\mathrm{A}$ & AB699877 \\
\hline Haplotype 3 & 27 & $\mathrm{~T}$ & $\mathrm{~T}$ & $\mathrm{C}$ & A & $\mathrm{C}$ & A & AB699878 \\
\hline
\end{tabular}


lower subsequent population size [20]. Moreover, introduced species are one of the most important factors for extinction of island population [5]. Native animals that inhabit islands have not experienced coevolution with introduced predators [21], and they are easy prey for those predators. In fact, it is thought that recent risk of extinction of the Ryukyu long-furred rat is a result of predation by feral cats and reduction of suitable habitat, C. sieboldii forest, in Okinawa-jima Island [22]. Habitat conservation and control of introduced predators are important for preventing extinction and loss of genetic diversity in Ryukyu long-furred rats.

The authors would like to thank Mr. M. Fukuda and Ms. S. Kunuyoshi at the Yambaru Wildlife Conservation Center (Ministry of Environment), Okinawa Prefectural Government and Small Indian Mongoose Eradication Project for providing the study animals, and Dr. H. Ishiniwa at the National Institute for Environmental Studies for advice on the analysis.

\section{REFERENCES}

1. Iwasa MA. 2009. Diplothrix legata (Thomas, 1906). In The Wild Mammals of Japan (Ohdachi SD, Ishibashi Y, Iwasa MA, Saitoh T. eds.), pp. 177. Shoukadoh Book Sellers, Kyoto.

2. Imazato H, Onuma M, Nagamine T, Nakaya Y. 2012. Molecular species identification of predators of endangered species on Okinawa-jima Island. Mammal Study 37: 159-164. 3. IUCN. 2014. The IUCN Red List of Threatened Species.

4. Ministry of the Environment Government of Japan. 2012. The 4th Red Data, The Threatened Wildlife of Japan - Red Data - Revised Edition.

5. Frankham R, Ballou JD, Briscoe DA. 2007. Genetics and extinction. In Introduction to Conservation Genetics. (Nishida M, Takahashi H, Yamazaki Y, Watanabe K trans.), pp. 45-69. Bun-ichi Co, Ltd, Tokyo (in Japanese).

6. Librado P, Rozas J. 2009. DnaSP v5: a software for comprehensive analysis of DNA polymorphism data. Bioinformatics 25: 1451-1452.

7. Saitou N, Nei M. 1987. The neighbor-joining method: a new method for reconstructing phylogenetic trees. Mol Biol Evol 4: 406-425.

8. Tamura K, Stecher G, Peterson D, Filipski A, Kumar S. 2013. MEGA6: Molecular Evolutionary Genetics Analysis version 6.0. Mol Biol Evol 30: 2725-2729.

9. Tajima F. Nei M. 1984. Estimation of evolutionary distance between nucleotide sequences. Mol Biol Evol 1: 269-285.

10. Felsenstein J. 1985. Confidence limits on phylogenies: An approach using the bootstrap. Evolution 39: 783-791.

11. Ozaki K, Yamamoto Y, Yamagishi S. 2010. Genetic diversity and phylogeny of the endangered Okinawa Rail, Gallirallus Okinawae. Genes Genet Syst 85: 55-63.

12. Hirota T, Hirohata T, Mashima H, Satoh T, Obara Y. 2004. Population structure of the large Japanese field mouse, Apodemus speciosus (Rodentia: Muridae), in suburban landscape, based on mitochondrial D-loop sequences. Mo Ecol 13: 3275-3282.

13. Rogers AR, Harpending H. 1992. Population growth makes waves in the distribution of pairwise genetic differences. Mol Biol Evol 9: 552-569.

14. Slatkin M, Hudson RR. 1991. Pairwise comparisons of mitochondrial DNA sequences in stable and exponentially growing populations. Genetics 129: 555-562.

15. Koike H. 2003. Syunaitakei to hozennidenngaku. In Conservation Genetics (Koike H, Matsui M. eds.), pp. 40-58. University of Tokyo Press, Tokyo (in Japanese).

16. Baba Y, Fujimaki Y, Yoshu R, Koike H. 2001. Genetic variability in the mitochondrial control region of the Japanese Rock Ptarmigan Lagopus mutus japonicus. Jpn J Ornithol 50: 53-64.

17. Gaines MS, Diffendorfer JE, Tamarin RH, Whittam TS. 1997. The effects of habitat fragmentation on the genetic structure of small mammal populations. J Hered 88: 294304.

18. Sax DF, Gaines SD. 2008. Species invasions and extinction: the future of native biodiversity on islands. Proc Nat Acad Sci USA 105 (Supplement 1), 11490-11497.

19. Frankham R. 1997. Do island populations have lower genetic variation than mainland population? Heredity 78 : 311-327.

20. Frankham R. 1998. Inbreeding and extinction: island populations. Conserv Biol 12: 665-675.

21. Fritts TH, Rodda GH. 1998. The role of introduced species in the degradation of island ecosystems: a case history of Guam. Annu Rev Ecol Syst 29: 113-140.

22. Kaneko Y. 2002. Ryukyu long-haired rat. In Threatened Wildlife of Japan -Red Data Book 2nd ed.- Volume 1, Mammalia. (Ministry of the Environment ed.), pp. 88-89. Japan Wildlife Research Center, Tokyo (In Japanese). 
Appendix 1 Sample list of Ryukyu long-furred rats used in this study.

\begin{tabular}{|c|c|c|c|c|c|c|c|c|c|}
\hline Year & Collected Date & Sample ID & Haplotype & Sex & Year & Collected Date & Sample ID & Haplotype & Sex \\
\hline \multirow[t]{5}{*}{2007} & Jan. 3 & $397 \mathrm{M}$ & 1 & Male & \multirow[t]{24}{*}{2011} & Apr. 14 & $2053 \mathrm{M}$ & 2 & Male \\
\hline & Mar. 16 & $420 \mathrm{M}$ & 2 & Female & & Mar. 22 & $2054 \mathrm{M}$ & 2 & Male \\
\hline & Nov. 23 & $636 \mathrm{M}$ & 2 & Female & & May. 16 & $2065 \mathrm{M}$ & 2 & Male \\
\hline & Dec. 9 & $645 \mathrm{M}$ & 3 & Female & & May. 22 & $2075 \mathrm{M}$ & 2 & Male \\
\hline & Dec. 12 & $646 \mathrm{M}$ & 3 & Female & & May. 31 & $2079 M$ & 2 & Male \\
\hline \multirow[t]{7}{*}{2009} & Apr. 9 & $989 \mathrm{M}$ & 2 & Female & & Jun. 20 & $2096 \mathrm{M}$ & 2 & Male \\
\hline & May. 9 & $1012 \mathrm{M}$ & 3 & Female & & Jun. 27 & $2104 \mathrm{M}$ & 2 & Female \\
\hline & Jun. 28 & $1078 \mathrm{M}$ & 3 & Male & & Jun. 30 & $2105 \mathrm{M}$ & 3 & Female \\
\hline & Jun. 30 & $1079 \mathrm{M}$ & 1 & Male & & Jul. 4 & $2107 \mathrm{M}$ & 1 & Male \\
\hline & Jul. 27 & $1100 \mathrm{M}$ & 3 & Male & & Jul. 7 & $2110 \mathrm{M}$ & 3 & Female \\
\hline & Oct. 20 & $1191 \mathrm{M}$ & 3 & Male & & Jul. 13 & $2117 \mathrm{M}$ & 2 & Male \\
\hline & Dec. 10 & $1204 \mathrm{M}$ & 2 & Male & & Jul. 31 & $2146 \mathrm{M}$ & 2 & Female \\
\hline \multirow[t]{18}{*}{2010} & Feb. 19 & $1280 \mathrm{M}$ & 3 & Male & & Sep. 2 & $2190 \mathrm{M}$ & 2 & Female \\
\hline & Feb. 27 & $1284 \mathrm{M}$ & 3 & Male & & Aug. 30 & $2202 \mathrm{M}$ & 3 & Male \\
\hline & Mar. 2 & $1288 \mathrm{M}$ & 2 & Female & & Sep. 11 & $2203 \mathrm{M}$ & 3 & Female \\
\hline & Mar. 26 & $1294 \mathrm{M}$ & 1 & Female & & Nov. 29 & $2259 \mathrm{M}$ & 2 & Male \\
\hline & Apr. 12 & $1311 \mathrm{M}$ & 3 & Male & & Dec. 9 & $2263 \mathrm{M}$ & 1 & Male \\
\hline & Apr. 19 & $1318 \mathrm{M}$ & 3 & $\mathrm{ND}$ & & Jul. 22 & $2295 \mathrm{M}$ & 1 & $\mathrm{ND}$ \\
\hline & May. 15 & $1344 \mathrm{M}$ & 3 & Female & & Aug. 1 & $2296 \mathrm{M}$ & 3 & ND \\
\hline & Jun. 18 & $1377 \mathrm{M}$ & 3 & Female & & Sep. 29 & $2300 \mathrm{M}$ & 3 & ND \\
\hline & Jun. 26 & $1405 \mathrm{M}$ & 3 & Male & & Oct. 3 & $2301 \mathrm{M}$ & 2 & ND \\
\hline & Jun. 29 & $1406 \mathrm{M}$ & 3 & Male & & Oct. 22 & $2302 \mathrm{M}$ & 2 & ND \\
\hline & Sep. 10 & $1768 \mathrm{M}$ & 2 & Male & & Nov. 22 & $2304 \mathrm{M}$ & 3 & ND \\
\hline & Sep. 29 & $1827 \mathrm{M}$ & 3 & Female & & Dec. 18 & $2306 \mathrm{M}$ & 3 & Female \\
\hline & Oct. 15 & $1831 \mathrm{M}$ & 2 & Male & \multirow[t]{6}{*}{2012} & Jan. 13 & $2343 \mathrm{M}$ & 2 & Male \\
\hline & Oct. 20 & $1844 \mathrm{M}$ & 2 & Male & & Jan. 14 & $2344 \mathrm{M}$ & 3 & $\mathrm{ND}$ \\
\hline & Nov. 2 & $1994 \mathrm{M}$ & 3 & Male & & Jan. 14 & $2345 \mathrm{M}$ & 1 & Female \\
\hline & Nov. 10 & $1995 \mathrm{M}$ & 3 & Male & & Jan. 24 & $2349 \mathrm{M}$ & 2 & Male \\
\hline & Dec. 5 & $1998 \mathrm{M}$ & 3 & Male & & Jan. 24 & $2398 \mathrm{M}$ & 2 & Female \\
\hline & Oct. 10 & $2001 \mathrm{M}$ & 2 & Male & & Jan. 30 & $2401 \mathrm{M}$ & 2 & Female \\
\hline
\end{tabular}




\title{
沖縄島北部におけるケナガネズミ（Diplothrix legata）の遺伝的多様性の評価
}

\author{
岡野 司 $^{1) *}$, 大沼 学 ${ }^{1)}$, 中田勝士 ${ }^{2)}$
}

1 ）独立行政法人国立環境研究所 $=305-8506$ 茨城県つくば市小野川 16-2

2 ）環境省やんばる野生生物保護センター ～９05-1413 沖縄県国頭郡国頭村比地 263-1

[2014 年 9 月 26 日受領, 2015 年 1 月 12 日採択 $]$

要 約

沖縄島北部のケナガネズミのミトコンドリア DNA の部分塩基配列を調べ，その遺伝的多様性を評価した。D-loop 領域の全塩基 配列と，tRNA-Pro および Pheの部分塩基配列を 60 個体において決定した。その結果，D-loop で 6 か所の塩基置換部位を持つ 3 つのハプロタイプが存在した。ハプロタイプ多様度（H）および塩基多様度（ $\pi ）$ は，それぞれ 0.606 および 0.00238 であた。 ミスマッチ分布解析により，沖縄島北部の集団がボトルネックを経験していることが示された。

キーワード : ケナガネズミ, 遺伝的多様性, D-loop

\section{*責任著者：}

岡野＼cjkstart司（E-mail: okano.tsukasa@nies.go.jp） 